\title{
Post-War Czechoslovakia: A Theoretical Critique
}

\author{
Tomáš Nikodym ${ }^{1}$ \\ Lukáš Nikodym² \\ Tereza Pušová ${ }^{3}$ \\ DOI 10.1515/jheec-2015-0014
}

\begin{abstract}
The paper focuses on the proposals of post-war order in Czechoslovakia and its theoretical analysis. While there exists a wide range of studies, both Czech and foreign, dedicated to the history of Czechoslovakia in the post-war period, a majority of the studies deals with political development. Then the interpretations of the failure of President Beneš' "distinct model of socialism" are purely political - weakness of President Beneš and democratic elites, the aggressive politics of Communist party, influence of Soviet diplomacy, etc. On the other hand, economic studies are only descriptive without theoretical analysis of proposed post-war order. Our paper offers different interpretation of the fall of Czechoslovak democratic regime (1945-1948). Using the framework of Austrian school, we are trying to show the institutional incompatibility of proposed post-war order. Special emphasis is put on the relation of freedom, democracy and socialist economic planning.
\end{abstract}

Keywords: democracy, economic planning, Czechoslovakia, post-war order JEL Classification: B13, N44, P21

\footnotetext{
1Department of Economic History; Faculty of Economic; University of Economics, Prague; Winston Churchill Sq. 4, 13067 Prague, Czech Republic; email: nikodym.tomas@gmail.com

2 Department of Economic History; Faculty of Economic; University of Economics, Prague

3 Department of Economic History; Faculty of Economic; University of Economics, Prague 


\section{Introduction}

"The main idea for the new post-war order has to be the realization that there cannot be a World War Three", that is how President Edvard Beneš started his considerations on the post-war order (Beneš 1946, p. 221). Like other Czechoslovak politicians, theorists and intellectuals, he was disappointed with the pre-war development which had led to the "Munich crisis" and the subsequent war. After analyzing the alleged causes of this crisis, they produced a description of the "new order": better, safe and just. In general, this new order was characterized by a merger of democracy and socialist economic planning.

Our study sets out to describe the proposed post-war order and to provide a theoretical analysis thereof. Emphasis will be placed on the matter of the compatibility between the institutions of democracy and socialism. The understanding of the various concepts of freedom also constitutes an integral part of the analysis, because different definitions of freedom can be perceived as the general starting point for all the considerations on the post-war order. In the first part of our study, we will describe the intellectual atmosphere in Czechoslovakia and its impact on the proposals for the post-war order. The following chapter will focus on a theoretical explanation of the concepts of freedom and the relationship between democracy and socialism. In the third chapter, we will apply the results of our theoretical analysis to the Czechoslovak proposals for the post-war order. Since we have not focused on political history, the theoretical analysis can help us to reach a different understanding of the rise of the totalitarian regime in post-war Czechoslovakia. We are able to use the theoretical analysis to reformulate the political causes of the communist revolution in 1948.

\subsection{Post-war Czechoslovakia}

"Liberalism, individualism, internationalism, universalism, ruralism, industrialism, capitalism, regionalism, statism - these words are only on paper, not in real life, but the worst 'ism' is politicism - overestimation of politics and underestimation of unpolitical spheres of life." - Jan Stránský

When considering the causes of the Munich Agreement and the subsequent war, Czechoslovak authors have mostly mentioned their disappointment with economic liberalism or capitalism in general. Vojta Beneš, the president's brother, for example, understood liberalism as the biological claim that life is a struggle and that the only benchmark is profit. When explaining the causes of the First World War, Vojta Beneš (1938, p. 71) blamed liberalism for all evils. "The beast in man, chained by gold and fed by the philosophy of liberalism for one hundred years, broke the chains...for the lies and idols of liberalism."Vojta Beneš understood the fall of the Western democracies in the 1930s similarly. For him, there was no doubt that it was liberalism which had caused the Munich crisis and the subsequent war. "Democracies formed right after the war were blessed with the most beautiful and most terrible gifts: the freedom and the desire for gold. Where they used their freedom for the fight for gold, they fell"(Beneš 1938, p. 155).According to the economist František Munk (1929) or the journalist Ferdinand Peroutka, liberalism had 
completely lost its power. Its fall was therefore inevitable and necessary for better future development (Znoj \& Havránek \& Sekyra 1995). Edvard Beneš saw the causes of World War Two as lying in the combination of economic and political issues. Firstly, he claimed that there was something irremediable in the Germans - they were aggressive panGerman imperialists by nature(Beneš 1946; Uhlír 1944).Secondly, the political causes lay in the inability of the Western democracies (especially France and Great Britain) to face up to Germany's aggressive policies. According to Beneš, this point was especially connected with the economic causes of World War Two. Beneš claimed that it was necessary to bring the economic and political systems of the Western democracies and the Soviet Union in the inter-war period closer together. In other words, the Soviet Union should shift its political system closer to the Western understanding of democracy and political freedom. On the other hand, Western democracies should make some economic and social reforms similar to those of the Soviet Union (Beneš 1946; Šrámek 1943; Bechyně 1948; Peroutka 1947).In Beneš' opinion, this did not happen because of the Western bourgeoisie. The Western bourgeoisie formed an alliance with fascism due to its fear of communism. While he criticized both the economic and political aspects of bourgeois democracy, it was mainly the economic aspect which he felt should have been changed (Beneš 1920; Stránský 1946; Šrámek 1945).

Based on his wartime experience, Edvard Beneš developed the idea of the post-war cooperation of Western democracies and the Soviet Union. While he completely refused the possibility of any cooperation between all kinds of fascism and democracy, he was sure that collaboration between the democracies and the Soviet Union was not only possible, but was also right and desirable. Of course, Beneš (1946) was not the only one who demanded wider cooperation between the West and the East. For example, Hubert Ripka (1944) claimed that the rapprochement of the Western democracies and Soviet Union took place a long time ago - not only at a technological level, but also at an ideological level. ${ }^{4}$ Peroutka, observing the political situation in Great Britain, concluded that there was no difference between the West and the East immediately after the war. "We can see the leftist East and the leftist West and the leftist middle between them. How can we expect that the leftism will disappear?", Peroutka (1947, p. 20) asked.

Actually, their considerations of the post-war order did not stop with the wider cooperation between the East and the West. Beneš continued with the question as to whether it is possible to implement Soviet economic principles in the Western democratic system. "My answer once again is yes", is how Beneš (1946, p. 256) summarized his thoughts, while the question as to the method of socialization remained. At this point, it is very important to mention that, while there were different proposals for the socialization of the economic sphere, this does not mean that "economic opposition" existed. Even the representatives of the so called "conservative right" had their own socialization proposals. For example, Jiří Hejda asserted that total economic planning is impossible, but he also refused laissez-faire and proposed the nationalization of enterprises by means of their

\footnotetext{
${ }^{4}$ We will focus on the understanding of the concepts of freedom later, but at this point, we can say that the claim about the ideological rapprochement of the East and the West was based on a socialist understanding of freedom. For Ripka, "equality" was at the material level and "equality of rights" was the same thing. He was then able to say that the Bolsheviks and the democrats had the same ideological basis.
} 
transfer in the form of joint-stock companies with the State as the majority shareholder (Hejda 1991, 1930).The anticipated leader of the "conservative right" and Minister of Finance in exile, Karel Ladislav Feierabend, thought differently. "It is impossible to turn the clock of economic life back. The government in exile in London has confirmed that the property transfers during the Nazi occupation are inoperative, but this does not mean that the former owners would have to get their property back"(Feierabend 1996, pp. 2021). ${ }^{5}$ Feierabend also supported economic planning, but he believed that this was possible without bureaucratic intervention and that entrepreneurial activity would be preserved. He thought that there was a difference between nationalization and directing and controlling the economy (Feierabend 1996; Opočenský 2001).The Foreign Minister, Jan Masaryk, agreed. “...I agree with Feierabend. No matter what happens, economic planning is necessary"(Němeček 2012, p.117).Peroutka (1947) confirmed that even a communist loss in the elections would not have prevented the socialization of the Czechoslovak economy. President Beneš himself did not support a socialist revolution, but a democratic evolution into socialism. He understood wartime destruction as the equalization of the rich and the poor, but this was not enough. He also realized that the wartime economy meant in fact the realization of a planned economy. That is also the reason why he refused the restoration of the market economy and the return of the property stolen by the Nazis to its rightful owners (Beneš 1946).

The combination of socialism and democracy was also understood as the liberation of the people. At first, they believed that socialism was the cure for business cycles and the "unjust" distribution of wealth and that it would also have meant a guarantee of higher productivity than capitalism. Secondly, socialism was also a means of breaking the employee-employer relationship which was often understood to be an involuntary contract; just because of physical needs such as food, clothing, etc. In other words, economic freedom was understood in post-war Czechoslovakia as liberation from needs, rather than the classic liberal concept of freedom. On the other hand, this was merely democracy considered as another word for freedom. "We admit that we are one of those who do not want democracy to disappear from socialism, since democracy is only other word for freedom. It is necessary to unite socialism and freedom.", is how Peroutka (1947, p. 112) explained his thoughts. The logical outcome was to "transfer" democracy from the political sphere to the economy. According to Peroutka (1947), this would mean that one person would stop serving another (Stocký 1940). President Beneš summarized his idea of the social order as follows: "We are fighting for a new social and economic order...We have accepted the democratic process in the political sphere. We shall be obliged after the present war to apply it to a very large degree in the social and economic spheres." 6

\footnotetext{
${ }^{5}$ We would like to mention the classic liberal Antonín Basch who refused these statements of the London government. According to Basch, it was necessary to return the stolen property to its rightful owner. At first, he was of the opinion that any form of compensation could not meet the requirements of justice. Secondly, the return of the stolen property to its owners should be undertaken as quickly as possible in order to speed up the economic recovery (Basch 1944).

${ }^{6}$ See The National Archives of the UK (TNA UK), FO 371/34343. Speech made by Dr. Benes at Manchester University on $5^{\text {th }}$
} December. 


\section{Theoretical Critique}

"Everything is what it is: liberty is liberty, not equality or fairness or justice or culture, or human happiness or a quiet conscience."-Isaiah Berlin "Property must be secured or liberty cannot exist." - John Adams

We have just seen the proposal for the "New Order". Let us briefly summarize the new system which is supposed to replace "bourgeois democracy" and establish a just society which will prevent future wars. Firstly, the starting point of all the proposals for the new economic system involved a specific understanding of the ideal of freedom. The perception of this ideal was positive rather than negative. In other words, the purpose was to free the individual from any wants and needs and from his or her dependence on others. For the sake of simplicity, we will call this concept the socialist ideal of freedom in this study. Whereas democracy was equal to freedom in politics, Beneš and others were of the opinion that this kind of freedom was still lacking in the economic sphere. The logical outcome was a proposal for the "democratization" of the economic sphere. ${ }^{7}$ In this case, it is very important to realize that the "democratization" of the economy was merely another name for socialism. Finally, economic planning was a means to free the individual and achieve a just society. The question as to whether it would be (and whether it is) possible to create such system still remains. We now intend to analyze the proposed means and discuss whether it was even possible to model such an institutional arrangement and achieve the prescribed goals.

\subsection{The concepts of freedom}

We will start with the definition of freedom and we then intend to focus on the relationship between democracy and freedom. Emphasis will be also placed on the concept of economic democracy followed by the economic problems pertaining to democracy itself. Finally, we will analyze the consequences of the impossibility of rational economic calculation under socialism in relation to the democratic institutional arrangement.

We are fully aware that people have been seeking freedom for millennia and as such a wide range of possible definitions exist (McMahon \& Dowd 2014). In our study, we only intend to focus on an analysis of the understanding of freedom in Czechoslovakia in the 1940s. This concept of freedom is equal to the one which Friedrich Hayek $(1976,1978)$ called "New Freedom" in his Road to Serfdom. According to this perception, freedom is not the freedom of individual action, but rather freedom from necessity or even freedom from the despotism of physical want. ${ }^{8}$ Many authors have emphasized that this understanding of freedom is merely the result of semantic confusion (often deliberate) which has confused freedom with "other good things" in the tradition of Rousseau's successors (McMahon \& Dowd 2014). According to Bruno Leoni (1972), this confusion merely involves the exploitation of words with a familiar sound in order to convince others to adopt new forms

\footnotetext{
7 The notion of the democratization of the economic sphere was developed earlier in Czechoslovakia. When introducing land reforms in 1919, Beneš' predecessor, President Masaryk, argued that there is a need for the redistribution of property rights to land from just a few owners to the people in general. During the realization of this policy, he refused to use the term "nationalization" or "socialization" and used the term "taking" instead. However, the property rights to the land were actually transferred to the state land office and the original owners could not dispose of the land.

${ }^{8}$ One of the champions of this socialist approach was Charles Fourier. His example helps us to fully understand the socialist position. From his point of view, abandonment (in the context of economic security) was one of the basic human rights. For him then, it was possible to rob others in the case of personal physical need, for example hunger (Nikodym 2014). 
of behavior. As Hayek (1976, p. 26) explained: "The demand for the new freedom was thus only another name for the old demand for an equal distribution of wealth. But the new name gave the socialist another word in common with the liberals, and they exploited it to the full." This semantic confusion went hand in hand with the definition of so-called fundamental rights. For example, Anton Menger claimed that socialists assumed three basic rights; the right to the full product of labor, ${ }^{9}$ the right to existence and the right to work (Mises 1981). It has been shown that similar rights were also proposed in post-war Czechoslovakia. Actually, the list of the claims was much longer in the post-war era. Max Hocutt(2012, p. 54) explained the success of this understanding of freedom and rights as follows: "Needs and wishes are limitless and claims are easy to make." He then continued by stating the consequences: "So, if every need, wish or claim constitutes a right, the concept no longer has definable meaning." Not only is the "wish list" limitless, but, according to the socialist approach to freedom, an individual is not free merely due to the fact that he or she has physical needs.

Firstly, freedom is a human concept and it is pointless to apply it outside society. Then, all attempts to consider freedom only within the framework of nature make no sense. The life of every individual depends upon natural conditions which are not subject to his or her will and the individual must subordinate him or herself to them (Mises 1981; Leoni 1972; Hayek 1978; Knight 1941).Hunger or the need for warm clothes does not make an individual unfree. As Rothbard explained, this concept is the result of the confusion between freedom and power. ${ }^{10}$ Of course, the lack of necessities can be considered within the framework of society. According to several theorists, whenever an individual lacks something he or she needs, the individual has been deprived of the item in question by those people who have it. In other words, they understood the dependency of the individual on other individuals as a lack of freedom. However, this concept does not really make sense. In fact, everyone is dependent on other people. While, for example, Peroutka claimed that the employee is dependent on the employer, in fact, the employee is no more dependent on the employer than on his or her neighbor. The main problem with this point of view is that Peroutka and others considered only one side of the mutual relationship. As Leoni (1972, p. 54) explained simply: "When a grocer or a doctor or a lawyer waits for customers or clients, each of them may feel dependent on the latter for his living. This is quite true. But if no customer or client makes his appearance, it would be an abuse of language to assert that the customers or clients who do not appear constrain the grocer or the doctor or the lawyer to die by starvation." The fact that they were only taking one side of the mutual relationship shows that this was more a means of propaganda than a serious analysis into what freedom really is. Even if we admit that dependency on others is a source of unfreedom, socialism would hardly be the desirable solution. There is no doubt that the means of production is dispersed among many individuals under the system of private property, while all these means are in the hands of the central planner under the socialism. As such, the planner has complete power over the individuals who are fully dependent

\footnotetext{
${ }^{9}$ In fact, this point makes no sense anymore. As Ludwig von Mises (1981) explained, that demand is quite absurd in light of the subjective theory of value. Hayek moved this argument forward. If socialist society claimed the full product of labor for everyone, this would necessarily lead to the very inequality of income which socialism opposes. The reason is simple. A worker in industry using a great deal of capital would have a much higher income than a worker using just a little capital (Hayek 1976).

${ }^{10}$ According to Rothbard (1998, p. 33): "Man, not being omnipotent as well as not being omniscient, always finds his power limited for doing all the things that he would like to do. In short, his power is necessarily limited by natural laws, but not his freedom of will." Knight (1941, p. 104) put it similarly. "Much of the protest against unfreedom reduces under examination to "kicking" against the unalterable facts of life, the possibilities of the world in which life is lived. What is ostensibly a demand for freedom is in fact largely a demand for power over other." 
upon his or her decisions. On the other hand, a single private owner can never achieve as much power as a planner. As Hayek (1976, pp. 103-104) pointed out: "...the system of private property is the most important guaranty of freedom, not only for those who own property, but scarcely less for those who do not." Another important point against the aforementioned concept of freedom was made by Barbara Wooton. This argument is much more interesting thanks to the fact that she was a socialist and very popular among Czechoslovak intellectuals. For all that, however, she understood the absurdity of freedom as being free from physical needs. According to Wooton, there is no doubt that a full belly and an educated mind are "good things" in and of themselves, but the use of these "good things" in the meaning of freedom from want and freedom from ignorance to describe desirable conditions would only lead to confusion which would obscure the real problems. She then continued as follows: "The condition of a well-fed, well-housed, well-clad, even well-entertained slavery is not an imaginary impossibility. It is only too possible. But it is not freedom. Freedom should not be defined in terms which, even by implication, deny the possibility that a high degree of material well-being may be accompanied by deprivation of freedom. Prisoners would not become free men even if they were looked after as well as race horses"(Wooton 1945, pp. 5-6). ${ }^{11}$ The possibility of "free" slaves and prisoners shows the absurdity of the socialist understanding of freedom..$^{12}$ As Leoni explained, while people often not only mean the absence of coercion by others, but also some guarantee of a satisfactory life when talking about "freedom from other men's constraint", these two goals are incompatible by nature. According to this logic, more coercion could mean more freedom (Leoni 1972).One of the latest famous "victims" of this confusion is, for example, Nobel Prize laureate Amartya Sen. When he talks about freedom, he actually means capacity. From his point of view, the greater the individual's capacity, range of choice, education, healthcare, etc., the greater the freedom. On the contrary: "The unfreedom links closely to the lack of public facilities and social care, such as the absence of an epidemiological program or organized arrangements for healthcare or educational facilities..."(Sen 1999, p. 4).He later offers a story from his childhood, when a man tried to find a job during some public riots. This man: "had to go out in search of work and a bit of earning, because his family had nothing to eat. The penalty of his economic unfreedom turned out to be death..."(Sen 1999, p. 8).Of course, it is a tragedy, but the man was not unfree. In fact, more questions appear using his approach and the answers would be necessarily arbitrary. Would Sen's approach change, if the man had had a job, but was killed during the riots while heading to his office? He had to work despite the riots, because he had to feed his family. What about a policeman suppressing the riots? He might have been killed at work, because he would have been there to earn some money to feed his family. Where is the line between the free and the unfree man? It seems that it is based on physical needs. As such, does anyone have "the right" to stay safelyat home and be nourished at the expense of others? If so, what will then be the incentive for people; to nourish or to be nourished?

\footnotetext{
11 While she fully understood the absurdity of the socialist concept of freedom, she also refused Hayek's concept defined in the Road to Serfdom. In fact, her book Freedom Under Planning was mentioned as a critique of Hayek's book. She tried to "bypass" the problems involving the definition of freedom by dividing it into partial freedoms (for example, the consumer's freedom to save or spend money). She then tried to show, for example, that planning is compatible with freedom, because the consumer can spend his money according to his will. However, in his review of Wooton's book, Chester Barnard (1946) pointed out that a thoughtful and critical reading of her book seems to substantially confirm Hayek's conclusions. As Hayek (1978, p. 19) concluded: "Liberties appear only when liberty is lacking."

12 The same idea was expressed well by Erik von Kuehnelt-Leddihn. He asked: "Who is sure of all his basic needs? Who has work, spiritual care, medical care, housing, food, occasional entertainment, free clothing, free burial, free everything?" Then he replied: “The answer might be 'the monks,' but the standard answer is: 'the jailbirds'."(Kuehnelt-Leddihn 1974, p. 104). 
Another problem with the aforementioned concept of freedom is that it does not have a clear meaning. It is not a universal concept which can be viewed as a single concept outside an ideology. Of course, we can "measure" the degree of freedom according to Stalinism or Nazism but nothing can be said about these freedoms outside the system (McMahon \& Dowd 2014). We have already indicated what the meaningful understanding of freedom is. Unlike the concept we criticized above, this understanding has only one meaning. The general concept of freedom is therefore necessarily negative (Rothbard 1998, Hayek 1978).A number of quotations will help to make this clear. As many authors agree, it is important to start with John Locke who was the "pioneer" of the negative concept of freedom (Hocutt 2012; McMahon \& Dowd 2014; Hayek 1998; Rothbard 1998). According to Locke, one man's freedom stops at the point where it interferes with another man's negative freedom. "...freedom is not, as we are told, 'a liberty for every man to do what he lists:' (for who could be free, when every other man's humour might domineer over him?) but a liberty to dispose, and order as he lists, his person, actions, possessions, and his whole property, within the allowance of those laws under which he is, and therein not to be subject to the arbitrary will of another, but freely follow his own"(Locke 1824, pp. 241242). ${ }^{13}$ Like Locke, many other thinkers realized the importance of property rights which were understood as an extension of the human being. In fact, this is a necessary condition for the concept of negative freedom. We have already quoted Hayek who explained private property as a guaranty of freedom, not only for the owners but equally for non-owners. Without property rights, man would be dependent on the arbitrary will of a central planner who controls property. As Mises (2002, p. 67) concluded: "Private property creates for the individual a sphere on which he is free of the state. It sets limits to the operation of the authoritarian will." 14 The importance of property is also rooted in the very nature of our world. Since material resources are scarce, according to Hayek property: "is the only solution men have yet discovered to the problem of reconciling individual freedom with the absence of conflict. Law, liberty and property are an inseparable trinity"(Hayek 1998, p. 107). In other words, the existence of private property is not the arbitrary decision of "evil capitalists" as many thinkers have claimed (and Czechoslovak thinkers have been no exception). As Hocutt (2012) emphasized, Locke believed that property rights are natural and in a sense "given by God", but in fact they are not dependent on this belief. We can only follow the origin of this institution. For example, Richard Pipes (1999) claims that historical research has shown that the institution of private property is not given by law or legislation, but that it is a natural institution common to all societies. ${ }^{15}$ Following this logic, this so-called natural institution does not mean an institution given by God, but the term natural is used in the sense of a natural and spontaneous adaptation to the conditions of the real world. And as we have mentioned above, one of the most important conditions is scarcity. Carl Menger (2011, p. 97) summarized that: “...human economy and property have a joint economic origin since both have as the ultimate reason for their existence the fact that goods exist whose available quantities are smaller than the requirements of men.

\footnotetext{
13 Of course, this idea is much older, but the work of John Locke constitutes the basis for the modern concept of freedom. As Leoni (1972, p. 14) pointed out, the ideal of the Confucian philosophy of "Do not do unto others that which you would not wish others to do unto you" had already been promoted in the Gospel. Fred McMahon and Alan Dowd (2014) similarly stressed the "ancient" inspiration in the theory of freedom.

14 The same idea has been expressed by John Tomasi (2012, p. 78). He claims that: "Ownership rights in productive property are not only important for the entrepreneur. Such rights free ordinary, working-class people from forced dependence on the state and its agents."

${ }^{15}$ A similar idea can be found in the work of Gerald Gaus. Gaus (2010, p. 252) argues that: "There has never been a political order characterized by deep respect for personal freedom that was not based on a market order with widespread private ownership in the means of production."
} 
Property, therefore, like human economy, is not an arbitrary invention but rather the only practically possible solution of the problem that is in the nature of things, imposed upon us by the disparity between requirements for and available quantities of all economic goods." While the principles of the negative concept of freedom are clear, there is no exact definition. For example, the conservative Kuehnelt-Leddihn (1952, pp. 2-3), one of the critics of the socialist definition of freedom mentioned above, claimed that: "Freedom means the greatest amount of self-determination which in a given situation is feasible, reasonable and possible." Then he continued that the socialist demand for equality is by its nature in direct conflict with freedom. At least three kinds of understanding of the negative concept of freedom can be found in the work of Friedrich Hayek. In his Road to Serfdom, Hayek (1976, p. 17) explained that: "In the ordering of our affairs we should make as much use as possible of the spontaneous forces of society and resort as little as possible to coercion..." A similar idea was expressed in his Constitution of Liberty. Coercion plays a major role once again. Then: "The state in which a man is not subject to coercion by the arbitrary will of another or others is often distinguished as 'individual' or 'personal' freedom, and whenever we want to remind the reader that it is in this sense we are using the word 'freedom,' we shall employ that expression"(Hayek 1978, p. 11).Later, in Law, Legislation and Liberty, Hayek focused more on the knowledge issue. According to Hayek (1998, p. 8), we can: "Describe these conditions [of freedom] as a state in which the individuals are allowed to use their own knowledge for their own purposes. "Hayek was not the only one who understood freedom as the absence of coercion. If fact, the same definition has been used, for example, by Bruno Leoni (1972) or Frank Knight (Buchanan 1999). Another conservative definition was introduced by Michael Oakeshott. He warned that the protection of freedom is undermined when it is valued for something other than itself (Segal 2003).He then identified the main condition of freedom as an absence of an over whelming concentrations of power (Oakeshott 1981). At this point, we want to recall Hayek, who claimed that private property is the best guarantee of individual freedom. Oakeshott (1981, p. 46) put it as follows: "The institution of property most favourable to liberty is, unquestionably, a right to private property least qualified by arbitrary limits and exclusions for it is by this means only that the maximum diffusion of the power that springs from ownership may be achieved." In other words, Oakeshott like Hayek understood the danger of the governmental control of the means of production which leads to the subordination of the individual to the government. "Wherever a means of production falls under the control of a single power, slavery in some measure follows."-is how Oakeshott (1981, p. 46) summarized the importance of private property as a means to achieve the "diffusion" of power.

As we have criticized the socialist understanding of freedom and proposed the negative concept, it is necessary to ask whether there is any need to reject the socialist definition completely. Isn't it possible to find a bridge between these two concepts of freedom? Let us return to Mises. While he did not accept the socialist definition of freedom, he realized what the socialists were promising. This has also been explained above. According to the socialist approach, the goal was to free men from the despotism of physical needs. They viewed socialism as a superior system to capitalism, because planning should increase productivity which would help to free men. As we have mentioned above, this idea was also widely accepted in Czechoslovakia. However, Mises (1981, p. 172) continued: "If [socialism] cannot do that, if on the contrary it diminishes productivity, then it will diminish freedom. "Since it cannot do so due to the impossibility of rational economic calculation (this will be explained more deeply in the last chapter of this study), socialism 
has lost its basis. However, we can still use its understanding of freedom and ask the question as to whether there is any way of increasing productivity and thus increasing the degree of socialist freedom. David Schmidtz and Jason Brennan (2010, p. 16) combined the negative and socialist definitions of freedom. "For example, where there are fewer obstacles to seeking employment of one's choice (fewer migration restrictions, fewer licensing or union membership requirements), are there fewer unemployed people?", they asked. Then they continued: "If so, then we can infer that negative freedom is positively liberating in that particular way. "To be clear, we still insist that there is only one freedom and that it exists only as a negative concept. Unlike Schmidtz and Brennan, we think that the equilibration of freedom and "wealth", "power" or other "good things" leads only to the confusion described above. "Freedom is an absence of constraints from other people, not the presence of something else. Coercing people requires the coercer to act, whereas leaving them free does not"(Palmer 2010).On the other hand, it is very useful to explain that the means proposed by the socialists cannot provide the promised results, i.e. socialist "freedom" or whatever is hiding behind this term. However, negative freedom can, of course, only provide these results indirectly. There are no such goals or values contained within freedom.

\subsection{Democracy and freedom}

"Because I love freedom, I hate democracy." - J. J. Bachofen

„Fully consistent democracy is impossible under capitalism, and under socialism all democracy will wither away." - Vladimir Ilyich Lenin

As we have mentioned above, democracy constituted equal freedom according to many Czechoslovak thinkers. Unfortunately, this claim is based on a misunderstanding of the principles of freedom and democracy themselves. In the previous section, we explained what freedom is. But what is democracy? For example, Joseph Schumpeter (2008) claimed that democracy is a political method. More rigorously, it is a type of institutional arrangement for reaching political decisions. Then, "the principle of democracy merely means that the reins of government should be handed to those who command more support than do any of the competing individuals or teams"(Schumpeter 2008, p. 273).To put it briefly, the question which democracy asks is who should exercise political power. In fact, this term contains no other content. As such, it would be fully compatible with democratic principles, if 51 per cent of the nation decided to establish a totalitarian regime, suppress the minorities, etc. (Kuehnelt-Leddihn 1952; Berlin 2002). On the other hand, with regard to freedom, the question is not who would exercise political power, but rather what limits are placed on political power or what the realm of the political sphere should be. This does not mean democracy is incompatible with freedom ${ }^{16}$ as defined above, but

16 We are fully aware that the existence of government itself can be viewed as the opposite of freedom, because of taxation, etc. This approach is typical to modern libertarianism. On the other hand, according to old-fashioned liberals, democracy is compatible with freedom, but only under the regime of the "minimal" state. This position was held, for example, by Mises. He stated that "the task of the state consists solely and exclusively in guaranteeing the protection of life, health, liberty, and private property against violent attacks. Everything that goes beyond this is an evil" (Mises 2002, p. 52). Knight (1941, p. 108) argued that: "The ideal of democracy is of course to minimize compulsion. "We do not want to use the libertarian analytical framework, since it excludes every possible form of government on the basis of coercive taxation. Anyway, the purpose of our study is not to design a "perfectly free society", but rather to analyze the proposal for the post-war order. This means that we do not need the ideal of a "perfectly free society" in order to evaluate whether the proposed system could possibly lead to a free society or a dictatorship. In other words, we want to evaluate "the direction" of the system, not how far it is from some ideal. For this purpose, we can use "softer assumptions" as to the fact that the democratic state can 
only that: "There is no necessary connection between individual liberty and democratic rule. The answer to the question 'Who governs me?' is logically distinct from the question 'How far does government interfere with me?'"(Berlin 2002, pp. 176-177). ${ }^{17}$ Given that democracy only involves a process of choosing the government or policies, it has nothing to say about freedom. According to Rothbard (2006), democracy can choose relatively laissez-faire policies on the one hand, but also interventionist or socialist programs with the high rate of interference on the other hand.

Hayek and Leoni also warned of the possible negative consequences of democracy on freedom. ${ }^{18}$ While many Czechoslovak theorists believed that the more democracy there would be, the better, this understanding is in direct contradiction to freedom. For Hayek, a classical liberal, the purpose of liberalism was to limit the coercive power of all governments. In his opinion, dogmatic democrats do not know the limits of government. Or rather, they know only one limit; majority opinion (Hayek 1978). Leoni (1972, p. 133) added: "These people pretend to champion democracy. But we ought always to remember that whenever majority rule is unnecessarily substituted for individual choice, democracy is in conflict with individual freedom." While McMahon and Dowd (2014) rightly understood that democracy is not freedom, they also claimed that democracy may be a "good thing". This statement may be misleading for some people. While it may be a "good thing", this does not necessarily mean that the more democracy, the better. Both Hayek and Leoni realized that democratic principles are not "always" good, because the democratic process could only provide answers to a limited number of questions. When the democratic process, for various reasons, unnecessarily substitutes individual action, it is in contradiction to freedom. We can also add another important argument set out by Franz Oppenheimer. He explained that there are two fundamentally opposed means of satisfying men's desires. "These are work and robbery, one's own labor and the forcible appropriation of the labor of others...I propose...to call one's own labor and the equivalent exchange of one's own labor for the labor of others "the economic means"...while the unrequited appropriation of the labor of others will be called the "political means..." As such, it is easy to summarize that: "The state is an organization of political means"(Oppenheimer 1914, pp. 24-27).To put it briefly, given that democracy is apolitical method, according to Oppenheimer this would mean more "political means" to the detriment of the "economic means". It is then similar to Hayek's (1976) claim that there would be no economic or social question that would not also be a political question under the planning system.

It is also possible to extend Oppenheimer's analysis to the problem of so-called economic democracy, which was a very popular idea among Czechoslovak theorists. For Mises, the existence of this concept is based on a misunderstanding of the nature and political function of democracy. In his opinion, the real function of democracy is to make a peace. As such, democratic institutions are merely a means to ensure that the will of the people becomes effective in political issues (Mises 1981). On the other hand, economic democracy

be compatible with freedom.

17 This idea was similarly expressed by Kuehnelt-Leddihn (1952), who tried to show that liberalism and democracy are based on different principles. Ortega y Gasset (1937, p. 125) realized that freedom "and democracy happen to be two things which begin by having nothing to do with each other, and end by having, so far as tendencies are concerned, meanings that are mutually antagonistic."

18 The main "positive effect" of democracy according to classical liberals was that democracy can provide a peaceful change of government, i.e. democracy is anti-revolutionary. This "feature" was stressed, for example, by Mises or Karl Popper (1956). "Democracy is not a revolutionary institution. On the contrary, it is the very means of preventing revolutions and civil wars. It provides a method for the peaceful adjustment of government to the will of majority", Mises (2002, p. 42) summarized the importance of democracy. 
is supposed to be the kind of the socialist order in which the workers, as producers and not as consumers, would decide what should be produced and how. According to Mises (1981, p. 11): "This state of affairs would be as little democratic as, say, a political constitution under which the government officials and not the whole people decided how the state was to be governed - surely the opposite of what we are accustomed to call democracy." In fact, economic democracy means the substitution of economic means with political ones. However, if we return to the original purpose of political democracy, i.e. to make the will of the people effective in political issues, and apply this idea in the economy, another definition of "economic democracy" occurs. Let us ask the question: under which conditions would the will of the people (consumers) be most effectively expressed in the economy? There is no doubt that it is the capitalist system with the profit motive, which provides the most efficient way of using scarce resources in a manner which consumers want. Briefly summarized, "the capitalist system of production is an economic democracy in which every penny gives a right to vote"(Mises 1944, p. 21).Or in other words, there is no need for the substitution of market principles, because free competition makes the will of the consumers effective in economic issues. ${ }^{19}$

Even before we focus on the relationship between democracy and socialism, we would like to briefly discuss some objections against the democratic system itself, especially the economic consequences. In the previous section, we explained why property rights are a necessary precondition for individual freedom. We have also outlined its important function in economic affairs. Then, as Hans-Hermann Hoppe (2007) pointed out, property rights are the key factor in establishing an individual time preference. Hoppe argued that the violation of property rights has an effect on the development of the time preference. While a crime, such as robbery, or natural disasters, such as floods, can cause a rise in the time preference, these changes in the time preference are not permanent, because a man can protect himself and his property against these violations. According to Hoppe, matters fundamentally change and the corruption of the time preference is permanent when the government violates property rights. The reason is simple; in this case, a man cannot legitimately defend himself and his property against the institutionalized violations. Under these circumstances, people would become more present-oriented. In other words, the important fall in the rate of the time preferences would be stopped, or even reversed. Since democratic government allows the expansion of violations of private property through its processes (for example, people may vote for the extensive redistribution of income), it may cause serious economic issues. As Bryan Caplan explained, despite the fact that democracy is presented as a political panacea, it can choose policies which are particularly harmful to most people. For example, every democratic country has had protectionist policies, while there is a consensus among economists that this is harmful to almost everyone. According to Caplan, people vote under the influence of false beliefs. Then, unlike other theorists who claim that democracy does not do what voters want, democracy fails in his opinion, because it does what voters want. "Garbage in, garbage out"(Caplan 2006, p. 2).Peter Boettke follows by stating that, if government action fails, the democratic system itself is never blamed, but in fact bad policies can be the outcome of the democratic process. As we have shown above, this was also the opinion of President Beneš who demanded changes in the economic sphere (Boettke 2001). Briefly summarized by Mises (1998, p. 193): “Democracy

\footnotetext{
${ }^{19}$ In a very recent study, John Tomasi (2012) has proposed a new concept of "market democracy". In his opinion, it is possible to combine the principles of classical liberalism, especially economic freedom, and the features proposed by modern liberalism. There are four defined principles of "market democracy": capitalist economic freedoms as vital aspects of liberty; society as a spontaneous order; just and legitimate political institutions as acceptable to all who make their lives among them, and finally social justice as the ultimate standard of political evaluation. 
guarantees a system of government in accordance with the wishes and plan of the majority. But it cannot prevent majorities from falling victim to erroneous ideas and from adopting inappropriate policies which not only fail to realize the ends aimed at but result in disaster."

\subsection{Democracy, democratic decision-making and economic planning}

"If socialism is a social necessity, then it would be human nature and not socialism which would have to readjust itself, if ever the two clashed." - Karl Kautsky

The relationship between democracy and socialism was not clear in the past. According to many authors, including in Czechoslovakia, democracy was only viable within a socialist regime. In this view, private control over the means of production was the source of political power (Schumpeter 1998; Mises 1981; Mises 1944).Another statement was made, for example, by Schumpeter. He argued that there is no necessary relationship between democracy and socialism. As such, the one can exist without the other, but more importantly Schumpeter (1998, p. 284) continued by stating that: "At the same time there is no incompatibility: in appropriate states of the social environment the socialist engine can be run on democratic principles." Frank Knight took a different position. In his opinion, economists have little to say about socialism, since it is a political problem. He then followed by stating that socialism has to be discussed in terms of social and political psychology (Rothbard 1991; Boettke \& Coyne 2004).

On the other hand, Mises argued that democracy is only possible under liberalism, not socialism. The reason is simple. Democracy, like liberalism, is not revolutionary. Liberalism, unlike socialism, tries to preserve the peace, because it is the basic condition for the attainment of the economic aims of man. Thusly, liberalism desires democracy. As he concluded: "The basic idea of liberalism and of democracy is the harmony of interest of all sections of a nation and then the harmony of interest of all nations"(Mises 1983, p. 71).On the other hand, the fundamental idea of socialism is not harmony, but the conflict of class interests. If this is then true, Mises states that they must consistently refuse democratic principles (Mises 1983; Mises 1981; Mises 1998).While we may agree with Mises, we also believe that rigorous analysis of the relationship between socialism and democracy is needed.

In a very recent study, Shruti Rajagopalan (2015) focused on the institutional arrangement of democracy and economic planning. She argued that, while the dream for a prosperous society is laudable, the institutions of socialism and democracy are in the conflict from the beginning. According to Rajagopalan, planners require unlimited discretion to execute the plan due to the impossibility of rational economic calculation under socialism. The impossibility of rational calculation was shown by Mises (1990; $1981 ; 1998)$ and later by Hayek $(1945 ; 1963)$. The problems of the socialist planner can be very briefly summarized as follows. According to Mises:

1) Without private property in the means of production, there will be no market for the means of production.

2) Without a market for a means of production, there will be no monetary prices established for the means of production.

3) Without monetary prices, reflecting the relative scarcity of capital goods, economic decision-maker will be unable to rationally calculate the alternative use of capital goods (Boettke 2001, p. 31). 
Hayek then continued his analysis by focusing on the knowledge problem. In short, Hayek argued that it is the market process itself, which creates the knowledge which is required for rational economic calculation. In other words, economic planning eliminates the emergence of economic knowledge. "The peculiar character of the problem of a rational economic order is determined precisely by the fact that the knowledge of the circumstances of which we must make use never exists in concentrated or integrated form, but solely as the dispersed bits of incomplete and frequently contradictory knowledge which all the separate individuals possess"(Hayek 1945, p. 519).

In our opinion, while the impossibility of rational economic calculation is an important part of the failure of socialism in general, it is not the main source of the incompatibility of democracy and economic planning. In our point of view, this main source of incompatibility was identified in another argument made by Rajagopalan, and even before by Hayek in his Road to Serfdom. The problem lies in the fact that while people democratically agree on the necessity of economic planning, their planning preference does not say anything about the contents of the plan. In Hayek's (1976, pp. 61-62) words: "The agreement on the desirability of planning is not supported by agreement on the ends the plan is to serve." In fact, it is impossible for all individuals in the society to agree on shared values and goals. Then, the creation and execution of the plan must be taken out of the democratic system and put into the hands of the "experts" independent of the democratic consensus. According to Hayek, a few socialists like Harold Laski or Sidney and Beatrice Webb admitted these problems by complaining about the incapability of democratic government to cope with its work, but the problem does not stop here. In fact, the nature of the plan excludes the possibility of democratic agreement on the plan's content. Or rather, by its very nature, a plan cannot be allowed to be made via the democratic process. As Hayek (1976, p. 67) summarized: "Yet agreement that planning is necessary, together with the inability of democratic assemblies to produce a plan, will evoke stronger and stronger demands that the government or some single individual should be given powers to act on their own responsibility." If such a plan is in direct conflict with personal freedom, the government will then have to decide whether to give up the planning or to suppress freedom and plan economic activity, because a dictatorship is the only way of enforcing the plan. ${ }^{20}$

Even if we assume for a while that it is possible to create a plan using the democratic process, another problem soon appears. As Samuel DeCanio argues, there are fundamental differences between the market and democratic decision-making. Both of them require a different kind of knowledge. He gives the simple example of car production. Suppose a democratic election only focuses on the production of a fuelefficient car. What knowledge is then required for the voters? In fact, voters have to understand which engine components would improve their car efficiency to vote for the "right" choice. In other words, car production via the democratic process requires some kind of "scientific knowledge"; in our case, engine design. Another part of the problem lies in the fact that voters must predict whether the cars would be produced efficiently. However, the efficiency of car production cannot be judged even ex post, because the voter can only observe the winning solution and not the alternatives which have failed in

20 While Knight (1938, p. 869) claimed that economics has little to say about socialism, he realized the unlimited power of the planner. Planners have to: "Exercise their power ruthlessly to keep the machinery of organized production and distribution running...They would have to do these things whether they wanted to or not; and the probability of the people in power being individuals who would dislike the possession and exercise of power is on a level with the probability than an extremely tender-hearted person would get the job of whipping-master on a slave plantation." Mises (1998, p. 689) expressed it more explicitly. He claimed that: „Every socialist is a disguised dictator.” 
the election. These issues do not occur in the market. As DeCanio explains: "While market prices reveal information regarding consumers' comparisons of rival firms' products, election margins reveal voters' comparisons of the incumbent's policy bundle with the hypothetical effects that might be produced by another party's bundle." Then he continues: "Since different parties' policies cannot be implemented simultaneously and compared, voter satisfaction with the incumbent party is measured relative to the hypothetical satisfaction they predict they will experience if another party is voted into power"(DeCanio 2014, p. 643).We can briefly summarize that the main difference between the market and democratic decision-making is the existence of the price system. The system of market prices eliminates the need for understanding scientific knowledge. Even if consumers are ignorant of engine design, their ignorance will not impede their satisfaction as long as they can compare the cars from competing producers. While market prices reflect the real satisfaction with preferences, the results of an election merely predict hypothetical satisfaction (DeCanio 2014).

A similar analysis was also undertaken much earlier by James Buchanan (1999). Even though he realized that there is better knowledge of the alternatives in the market, he assumed the same degree of knowledge in democratic decision-making for the purposes of his analysis. He then defined approximately six main differences between the market choice and democratic decision-making. The most important of these for our analysis are the degree of certainty, the degree of responsibility and the degree of coercion. According to first point, there is an inherent uncertainty in democratic decision-making, since the voter can never predict the behavior of others. On the other hand, in the market, the individual is the only actor and the entity for which the choice is made. Considering the responsibility, democratic voting means a collective choice. The responsibility for the individual choice is then necessarily divided, while the responsibility in the market is concentrated on the actor who made the choice. According to Buchanan, this difference leads to a more objective consideration of the alternative costs. And finally, Buchanan, like DeCanio, realized that the voter does not choose from existing alternatives in the democratic process, but from potential ones. Unlike in the market, the voter is forced to accept the results of the choice in the democratic process despite his original choice. This kind of coercion is never present in the market." If rationality in individual behavior is considered a desirable feature of a choice process, there would appear to be several reasons for claiming that market choice should be preferred", is how Buchanan (1999, p. 85) summarized his analysis. He also put the results of the analysis into a relationship with freedom. He then concluded that the market should be preferred when considering freedom. "The absence of negative results of individual choices and, therefore, of the direct coercion which requires that the individual accept unchosen alternatives makes for a greater degree of freedom in market choice"(Buchanan 1999, p. 86).

Moreover, in his critique of Kenneth Arrow, he stressed the difference between voting and the market mechanism as decision-making processes. According to Arrow, neither the market nor democratic voting can successfully aggregate the individual values into a social welfare function. Since only the individual is rational, Arrow was led to the conclusion that collective choices are either democratic, but irrational and inefficient, or they are rational, but dictatorial in that the choice is made by a single individual with unlimited power (Boettke \& Leeson 2002).Buchanan explained that Arrow had failed to recognize the differences between the democratic and market choice. In fact, there is no need for the social welfare function in the market, since only the individual decides what has value. In other words, a social-value scale does not exist, but market can deliver 
consistent choices. ${ }^{21}$ Buchanan (1999, p. 102) thus argued that: "The possible inconsistency is a necessary characteristic of orderly majority rule." On the other hand, the market can "produce consistent choice, in spite of the fact that a 'satisfactory social welfare function' cannot be derived from the individual rankings implicit in the market mechanism." Moreover, Boettke (2001) pointed out that it is possible to reinterpret Arrow's claim as an application of the impossibility of non-market decision-making via democratic voting as proposed by Mises. As mentioned above, there is no possible way of making a rational economic calculation in the absence of market prices. It does not matter whether the planning is democratic or dictatorial. In fact, Arrow showed that even market socialism cannot work. Like other forms of socialism, even market socialism required an ex ante social welfare function. Since it is impossible to aggregate such a function, market socialism is not viable. Then, according to Buchanan, Arrow's analysis implied that: "If we cannot aggregate individual preferences, no matter whether or not the other problems emerge, socialism is impossible"(Boettke \& Leeson 2002, p. 18).

\section{Summary}

In February 1948, the Communist party took power in Czechoslovakia and shaped all the political and economic life for the next 41 years. Classic historical analysis has mostly focused on a political explanation for the communist coup d'etat. Using the political explanation, historians have often claimed that, if Beneš' government in exile had been stronger and had pushed its proposed post-war order through the political process, the development of Czechoslovakia could have been different in the following years. However, our analysis has shown that the proposal made by president Beneš and his government in exile was unable to achieve the proposed aims from the very beginning. We have shown that the theoretical foundations of their post-war order were based on an incompatible institutional arrangement. At first, the authors of the proposal did accept the socialist definition of freedom. Naturally, socialism was the means to attaining the planned state of affairs; a new and just society. Although we claim that there is only one meaningful definition of freedom, we have also shown that the socialist definition of freedom was incompatible with the presumed method of implementation. Since socialism lacks the means of rational economic calculation, it cannot be more productive than capitalism. The same applies to the combination of democracy and socialism which was to have been the main feature of the "new order". In our opinion, democracy and socialism are incompatible, because economic planning needs to be independent of democratic control in order to be real planning, since the creation of the plan via the democratic process is absurd. Once again, the impossibility of socialism only strengthens this argument. Then the choice is to waive the socialism and preserve the democracy or to push the socialism forward and create some kind of authoritative regime. According to the results of our analysis, we can state that the road to the authoritative regime started much earlier than in 1948. The intellectual atmosphere among the political elite meant that there was no other option.

There were in fact a few authors who realized the dangers of the proposed post-war order. We can quote the economist Karel Engliš, for example. In 1947, Engliš stated during a speech that: "Where economic liberalism is knocked down, authoritative

${ }^{21}$ A similar critique was made, for example, by Mises (1998, p. 230). For him, it was only the individual who values and makes the economic calculation. "[Monetary calculation] involves calculating the individuals' profit, not imaginary 'social' values and 'social' welfare." 
planning extends into the political sphere... The State which controls the economy wants to control the thoughts of the whole Nation to secure its planned economic system"(Vencovský 1993, p. 125).According to Antonín Basch, the socialist and interventionist proposals would have made European unification much harder than in the case of a liberal economic order. He also recognized the incompatibility of the proposed order with individual freedom. "Society may truly look to the human being as its central concern, instead of to the omnipotent state in which he is only an item in a total plan"(Basch 1941, p. 186).In the end, we can return to Ferdinand Peroutka. As we mentioned before, he was one of the advocates of the "new order". Unfortunately, it was too late for him to realize in 1948 what the "new order" actually meant. After the communist coup d'etat, Peroutka (1993, p. 15) summarized the post-war development thus: "The fruit of freedom which the London government offered was wormy. London exile stood with the winners against Hitler, but on the other hand, they lost almost everything. They claimed they were bringing freedom, but they just brought almost perfect communist revolution."

\section{References}

Barnard, Ch. 1946, Freedom Under Planning: Review, in: Southern Economic Journal, Vol. 12, No. 3, pp. 290-300

Basch, A. 1944, Industrial Property in Europe. New York, Committee on International economic policy in cooperation with The Carnegie endowment for international peace

Basch, A. 1941, The New Economic Warfare. New York, Columbia University Press

Bechyně, R. 1948,Pero mi zůstalo. Praha, Dělnické nakladatelství (Collected Works)

Beneš, E. 1946,Demokracie dnes a zítra. Praha, Čin (Democracy today and tomorrow)

Beneš, E 1947. Paměti: Od Mnichova k nové válce a k novému vítězství. Praha, Orbis (Memoirs: From Munich Crisis to the New War and the New Victory)

Beneš, E. 1920,Povaha politického stranictví. Praha, Vydáno péči ministerstva školství a národní osvěty ve Stát. škol. knihoskladě (On political parties)

Beneš, E. 1946,Šest let exilu a druhé světové války: řeči, projevy a dokumenty z r. 1938-45. Praha, Orbis (Six year of exile and WWII: Speeches and documents 1938-1945)

Beneš, V. 1938,O humanitní demokracii: sebrané stati. Praha, Svaz národního osvobození (On humane democracy)

Berlin, I. 2002 Two Concepts of Liberty. In HARDY, H.(ed.). Liberty: Incorporating Four Essays on Liberty, Oxford

Boettke, P. 2001,Calculation and Coordination, New York, Routledge

Boettke, Pand Coyne, Ch. 2004, The Forgotten Contribution: Murray Rothbard on Socialism in Theory and in Practice, in: The Quarterly Journal of Austrian Economics, Vol. 7, No. 2, pp. 71-89.

Boettke, P. - Leeson, P. 2002, Hayek, Arrow, and the Problems of Democratic DecisionMaking, in: Journal of Public Finance and Public Choice, Vol. 20, No. 1, pp. 1-39.

Buchanan, J. 1999, The Collected Works of James M. Buchanan I: The Logical Foundations of Constitutional Liberty, Indianapolis, Liberty fund

Caplan, B. 2006, The Myth of the Rational Voter, Princeton and Oxford, Princeton University Press

DeCanio, S. 2014, Democracy, the Market, and the Logic of Social Choice, in: American 
Journal of Political Science, Vol. 58, No. 3, pp. 637-652.

Feierabend, L. K. 1996,Politické vzpomínky III. Brno, Atlantis (Political memoirs)

Gaus, G. 2010, Coercion, Ownership, and the Redistributive State: Justificatory Liberalism's

Classical Tilt, in: Social Philosophy and Policy, Vol. 27, No. 1, pp. 233-275.

Hayek, F. A. 1963, Collectivist Economic Planning, London, Routledge

Hayek, F. A. 1998,Law, Legislation and Liberty: A new statement of the liberal principle of justice and political economy, London, Routledge

Hayek, F. A. 1978, The Constitution of Liberty, Chicago, Chicago University Press

Hayek, F. A. 1976, The Road to Serfdom, Chicago, Chicago University Press

Hayek, F. A. 1945, The Use of Knowledge in Society, in: The American Economic Review, Vol. 35, No. 4, pp. 519-530

Hejda, J. 1930,Hospodářská funkce akciové společnosti. Praha, Česká národohospodářská společnost (Economic function of joint-stock company)

Hejda, J. 1991,Žil jsem zbytečně: Román mého života. Praha, Melantrich (Memoirs: My life was wasted)

Hocutt, M. 2012, Rights: Rhetoric versus Reality, in: Independent Review, Vol. 17, No. 1, pp. $51-64$

Hoppe, H-H. 2007,Democracy, The God That Failed: The Economic and Politics of Monarchy, Democracy, and Natural Order, New Brunswick, Transaction Publishers

Knight, F. 1938, Lippmann's The Good Society, in: Journal of Political Economy, Vol. 46, No. 6, pp. 864-872

Knight, F. 1941, The Meaning of Freedom, in: Ethics, Vol. 52, No. 1, p. 86-109

Kuehnelt-Leddihn, E. 1974, Leftism: From de Sade and Marx to Hitler and Marcuse, New York, Arlington House Publishers

Kuehnelt-Leddihn, E. 1952, Liberty or Equality: The Challenge of our Time, Caldwell, The Caxton Printers

Lecky, W. 1903,Democracy and Liberty, New York, Longmans, Green, and Co.

Leoni, B. 1972,Freedom and the Law, Los Angeles, Nash Publishing

Locke, J. 1824, The Works of John Locke in Nine Volumes, London, Rivington

McMahon, F. and Dowd, A. 2014, Human Freedom: From Pericles to Measurement, in Independent Review, Vol. 19, No. 1, pp. 65-84

Menger, C. 2011,Principles of Economics, Auburn, Ludwig von Mises Institute

Minogue, K. 2009, The Elusive Oakeshott, in: The American Conservative, October, pp. 24 26

Mises, L. 1944, Bureaucracy, New Haven, Yale University Press

Mises, L. 1990,Economic Calculation in the Socialist Commonwealth, Auburn, Ludwig von Mises Institute

Mises, L. 1998,Human Action: A Treatise on Economics, Auburn, Ludwig von Mises Institute

Mises, L. 1998, Interventionism: An Economic Analysis, Irvington, The Foundation for Economic Education

Mises, L. 2002,Liberalism, Auburn, Ludwig von Mises Institute

Mises, L. 1983,Nation, State and Economy: Contribution to the Politics and History of Our Time, New York, New York University Press

Mises, L. 1981, Socialism: An Economic and Sociological Analysis, Indianapolis, Liberty fund 
Munk, F. 1929,Nové hospodářství: studie o hospodářské revoluci XX. století. Praha, Orbis (New economy: On the economic revolution of 20th century)

Němeček, J.(ed.), 2012,Zápisy ze schůzí československé vlády v Londýně. III. 1 (leden červen 1943). Praha, Historický ústav Akademie věd ČR (Records of Czechoslovak government meetings in London)

Nikodym, T. 2014,Z knihovničky utopického socialismu, Praha, Ludwig von Mises Institut (On utopian socialism)

Oakeshott, M. 1981,Rationalism in Politics and other essays, New York, Methuen

Opočenský, J. 2001,Válečné deníky Jana Opočenského, Praha, Karolinum (War diaries)

Oppenheimer, F. 1914, The State: Its History and Development Viewed Sociologically, New York, Vanguard Press

Ortegga Y Gasset, J. 1937,Invertebrate Spain, New York, W.W. Norton \& Co.

Palmer, T. 2010,Liberty is Liberty, URL: http://www.cato-unbound.org/2010/03/12/tom-gpalmer/liberty-liberty

Peroutka, F. 1993,Byl Edvard Beneš vinen?. Jinočany, H \& H (Was Edvard Beneš quilty?)

Peroutka, F. 1947,Tak nebo tak. Praha, Fr. Borový (One way or another: Collected Works)

Pipes, R. 1999,Property and Freedom, New York, Alfred A. Knopf

Popper, K. 1956, Die öffentliche Meinung im Lichte der Grundsätze des Liberalismus, in: ORDO: Jahrbuch für die Ordnung von Wirtschaft und Gesellschaft, Vol. 8, pp. 7-17

Rajagopalan, S. 2015, Incompatible institutions: socialism versus constitutionalism in India, in: Constitutional Political Economy, Vol. 26, No. 3, pp. 328 - 355

Ripka, H. 1944,S východem a západem. Londýn, Nákladem Čechoslováka (With the East and the West)

Rothbard, M. 1998,Ethics of Liberty, New York, New York University Press

Rothbard, M.2006, Power and Market: Government and the Economy, Auburn, Ludwig von Mises Institute

Rothbard, M. 1991, The End of Socialism and the Calculation Debate Revisited, in: The Review of Austrian Economics, Vol. 5, No. 2, pp. 51-76

Schumpeter, J. 2008,Capitalism, Socialism and Democracy, New York, HarperCollins

Segal, J. 2003, Freedom and Normalization: Poststructuralism and the Liberalism of Michael Oakeshott, in: The American Political Science Review, Vol. 97, No. 3, pp. 447-458

Sen, A. 1999,Development as Freedom, New York, Anchor Books

Schmidtz, D.and Brennan, J. 2010,A Brief History of Liberty, Hoboken, Wiley-Blackwell

Socký, J. 1940,O zásadách plánování v hospodářském prostoru. Praha, Česká společnost národohospodářská (On economic planning in Czechoslovakia)

Stránský, J. 1946,Hovory k domovu. Praha, Fr. Borový (Speeches home)

Šrámek, J. 1943, Jednota vskutku národní, in:Čechoslovák, 28. 10. 1943, No. 43-44, pp. 1-2 (National Unity)

Šrámek, J. 1945,Politické projevy v zahraničí. Praha, Výkonný výbor československé strany lidové (Political speeches)

The National Archives of UK (TNA UK), FO 371/34343. Speech made by Dr. Benes at Manchester University on 5th December.

Tomasi, J. 2012, Free market fairness, Woodstock, Princeton University Press

Uhlír, F. 1938,Prague and Berlin 1918-1938. London, Hutchinson

Vencovský, F. 1993,Karel Engliš. Brno, Universitas Masarykiana 
Tomáš Nikodym, Lukáš Nikodym, Tereza Pušová - Post-war Czechoslovakia: A theoritical critique

Wotton, B. 1945,Freedom Under Planning, Chapel Hill, The University of North Carolina Press

Znoj, M. and Havránek, J. andSekera, M. (eds.), 1995,Český liberalismus: texty a osobnosti. Praha, Torst (Czech liberalism: texts and people 